Original Research Paper

\title{
Desorption of Exchangeable Cations at Adsorption of Lead Ions by Chernozem in the Presence of Attendant Anions
}

\author{
${ }^{1}$ Minkina, T.M., ${ }^{2}$ D.L. Pinskii, ${ }^{1}$ S.S. Mandzhieva, ${ }^{1}$ T.V. Bauer, \\ ${ }^{3}$ A.A. Batukaev, ${ }^{1}$ S.N. Sushkova, ${ }^{1}$ A.K. Sherstnev and ${ }^{4}$ S.U. Bakoev \\ ${ }^{1}$ Southern Federal University, 344090, 194/1 prosp. Stachki, Rostov-on-Don, Russia \\ ${ }^{2}$ Institute of Physical, Chemical and Biological Problems of Soil Science RAS, 142290, 2, Institytskaya St., Pyshino, Russia \\ ${ }^{3}$ Chechen State University, 364907, Sheripov St., 32, Grozny, Chechen Republic, Russia \\ ${ }^{4}$ Don State Agrarian University, 346493, Persianovskii, Rostov-on-Don oblast, Russia
}

Article history

Received: 17-08-2015

Revised: 08-09-2015

Accepted: 07-10-2015

Corresponding Author:

Mandzhieva, S.S.

Southern Federal University, 344090, 194/1 prosp. Stachki,

Rostov-on-Don, Russia

Email:msaglara@mail.ru

\begin{abstract}
The effect of $\mathrm{Cl}^{-}, \mathrm{Ac}^{-}$and $\mathrm{NO}_{3}^{-}$anions on the adsorption of $\mathrm{Pb}$ cations by an ordinary chernozem and desorption of exchangeable cations in the soil-solution system has been assessed under model laboratory conditions. It has been shown that the attendant anions affect the shape of the adsorption isotherms, which are described by the Langmuir equation. The greatest influence on the affinity constant of $\mathrm{Pb}$ with soil has anion $\mathrm{Ac}^{-}$. It has been found that the uptake of the $\mathrm{Pb}$ cations by chernozem from solutions of different salts is accompanied by the displacement of the exchangeable cations to the solution in the following order: $\mathrm{Ca}^{2+}>\mathrm{Mg}^{2+}>$ $\mathrm{Na}^{+}>\mathrm{K}^{+}$. The sum of the displaced exchangeable cations in most cases exceeds the amount of the adsorbed metal cations. The content of $\mathrm{Pb}$ cations desorbed by the ammonium acetate buffer solution ( $\mathrm{pH} 4.8$ ) makes up $6-39 \%$ of the total $\mathrm{Pb}$ adsorbed cations. According to the effect of the anions on the displacing capacity of cations for $\mathrm{Pb}$ the following series are formed: $\mathrm{Cl}^{-}>\mathrm{Ac}^{-}>\mathrm{NO}_{3}^{-}$.
\end{abstract}

Keywords: Adsorption, Attendant Anions, Chernozem, Desorption, Exchangeable Cations, Lead

\section{Introduction}

At the present, the contamination with Heavy Metals (HMs) constitutes a serious environmental danger. Among the HMs, copper is one of the priority environmental pollutants. Lead is a highly technophilic element, which finds wide use in industry. It arrives into the environment from technogenic sources and actively affects all the environmental components. Soils are subject to the maximum load (Panin and Siromlya, 2005). This is related to the capacity of soils to strongly fix $\mathrm{Pb}$ into low-mobile compounds and thus fulfill the role of natural buffer and detoxicant.

It is known that most of HMs emitted by industrial enterprises and motor vehicles as aerosols arrive into the soil in the form of oxides, oxyhydroxides, carbonates, chlorides, sulfates and phosphates. However, problems related to the effect of the chemical form of a HM on its adsorption by the soil remain to be studied (Wang and Harrell, 2005; Davis and Leckie, 1978; Guilherme et al., 2003; Puls and Bohn, 1988).
The transformation of technogenic $\mathrm{Pb}$ compounds in the soil starts from their dissolution in soil water. For the hardly soluble $\mathrm{Pb}$ compounds, this is the first and the slowest stage of their transformation (Ladonin and Karpukhin, 2011). According to Zaplina (1994), the time of the complete dissolution of HM oxides added to the soil in the amounts corresponding to the actual contamination levels can be from six months to tens of years. Other authors (Parnunina, 1983; Gorbatov, 1988) studying the transformation kinetics of $\mathrm{Pb}, \mathrm{Cd}$ and $\mathrm{Zn}$ oxides, as well as of silt containing these HMs, in soils, on the contrary, noted the high dissolution rate of metal oxides and the adsorption of their ions on the surface of soil particles.

The equivalence of cation exchange in soils still remains a debatable problem. The effect of salt anions on the balance of the displaced cations is worst understood. In accordance with the ion exchange theory, the adsorption of some cations should be accompanied by the displacement of an equivalent amount of other 
cations, including $\mathrm{H}^{+}$, from the Soil Exchange Complex (SEC). However, real experiments frequently give contradictory results. Panin and Siromly (2005) generally noted an equivalence of ion-exchange processes with consideration for the released hydrogen. However, some studies were performed with monoionic Ca-saturated soils (Minkina et al., 2011; Pinskii, 1997), which makes incorrect the comparison of their results with the data for soils with a natural composition of the exchangeable cations.

The involvement of all the cations and different anions present in the system and capable of exchange in the sorption is an important aspect of adsorption processes in natural soils (Minkina et al., 2014). The anionic composition of the salt containing a Heavy Metal (HM) can have a qualitative and quantitative effect on the exchange of cations in the soil-solution system.

The aim of this work was to study the balance of $\mathrm{Pb}$ cations adsorbed from different salt solutions and the amount of exchangeable cations displaced from the SEC.

\section{Materials and Methods}

\section{Soil}

A heavy loamy ordinary chernozem on loess-like loam (ID 14-2, FAO, 1988) from Rostov region was used as the object of the study. Samples were taken from the -0 to $20 \mathrm{~cm}$ layer and had the following physical and chemical parameters: Corg, 2.3\%; $\mathrm{pH}, 7.3$; CEC, $3.71 \mathrm{mM} \mathrm{kg}^{-1}$; exchangeable bases, $\mathrm{mM} \mathrm{kg}^{-1}$ : $\mathrm{Ca}^{2+}, 3.95 ; \mathrm{Mg}^{2+}, 5.5 ; \mathrm{Na}^{+}, 0.01 ; \mathrm{K}^{+}$ex. 0.058 ; clay (the particle with size $<0.01 \mathrm{~mm}$ ), $53.1 \%$; silt (the particle with size $<0.001 \mathrm{~mm}), 32.4 \% ; \mathrm{CaCO}_{3}, 0.1 \% ; \mathrm{P}_{2} \mathrm{O}_{5 \mathrm{mob}}$, $1.6 \mathrm{mg} / 100 \mathrm{~g}$. Soil properties were analyzed using Russian standard methods (AMSS, 1990). Analytical quality of the measurements was controlled by analyzing reference standard soil sample "Chernozem" № 29107. Duplicates and reagent blanks were also used as a part of the quality control.

\section{Adsorption Experiment}

The soil in the natural ionic form sieved through a $1 \mathrm{~mm}$ sieve was used in the studies. The concentrations of the initial $\mathrm{Pb}$ (Cini) solutions varied in the range from 0.05 to $1 \mathrm{mM} \mathrm{L}^{-1}$. The selection of the metal concentration range is determined by the existing levels of the soil contamination with pollutants. The samples of soil in the natural cationic form were treated with solutions of $\mathrm{Pb}$ nitrates, acetates and chlorides at a soil: Solution ratio of 1: 10 . The suspensions were shaken for $1 \mathrm{~h}$ and left to stand for $24 \mathrm{~h}$. The $\mathrm{pH}$ values were measured in the equilibrium solutions by potentiometry. Then, the suspensions were filtered. The contents of $\mathrm{Ca}^{2+}, \mathrm{Mg}^{2+}$,
$\mathrm{Na}^{+}$and $\mathrm{K}^{+}$were determined by the Shaimukhametov method (AMSS, 1990). The content of $\mathrm{Pb}^{2+}$ in the filtrates was determined by atomic absorption spectroscopy (Kvant-2A). The contents of the adsorbed $\mathrm{Pb}$ cations were calculated from the difference between the metal concentrations in the initial and equilibrium solutions. Sorption isotherms were constructed by plotting the sorbed metal content of the soil (mM per of dry soil) against the concentration of the metal in solution at equilibrium $\left(\mathrm{mM} \mathrm{L}^{-1}\right)$.

The desorption of the adsorbed $\mathrm{Pb}$ in the soil (their mobile form) was assessed by their extraction with a $1 \mathrm{~N}$ ammonium acetate solution at $\mathrm{pH} 4.8$ with a soil: Solution ratio of 1: 5 . The time of the extraction was $18 \mathrm{~h}$ (Minkina et al., 2008).

\section{Statistical Analysis}

The experiments were carried out in triplicate. All statistical calculations were performed using Microsoft Excel 2010. The approximation of the experimental isotherms by the Langmuir equation was performed using the SigmaPlot 2001 statistics package at a confidence probability of 0.95 .

\section{Results}

The adsorption isotherms of $\mathrm{Pb}$ cations from chloride, nitrate and acetate solutions are given in the Fig. 1. The isotherm's shape is determined by the character of the adsorbate-adsorbent interaction: The more convex the isotherm, the stronger the adsorbate is retained by the adsorbent.

The adsorption of $\mathrm{Pb}$ by the soils is most frequently described by the Langmuir equation. The Langmuir equation is derived from the model concept of the adsorption process and has the form:

$C_{a d s .}=C_{\max } K_{L} C /\left(1+K_{L} C\right)$

Where:

$C_{a d s}=$ The content of the adsorbed cations

$C_{\max }=$ The maximum adsorption of the $\mathrm{HM}, \mathrm{mM} \mathrm{kg}^{-1}$ soil

$K_{L}=$ The affinity constant, $\mathrm{L} \mathrm{mM}^{-1}$

$C=$ The concentration of the HM in the equilibrium solution, $\mathrm{mM} \mathrm{L}^{-1}$

The parameters of the $\mathrm{Pb}$ adsorption calculated from these equations are given in Table 1 . The approximation quality of the experimental isotherms by these equations is characterized by high determination coefficients $\left(R^{2}\right)$. The analysis of the data (Table 1 ) shows that the effect of the attendant anions on the values of $C_{\max }$ for the studied $\mathrm{Pb}$ cations varies in the following series: $\mathrm{Cl}^{-}>$ $\mathrm{NO}_{3}^{-}>\mathrm{Ac}^{-}$. 
Table 1. Parameters of the Langmuir equation for the adsorption of $\mathrm{Pb}$ from different salt solutions by an ordinary chernozem

\begin{tabular}{llll}
\hline Metal application form & $\mathrm{C}_{\max }, \mathrm{mM} \mathrm{kg}^{-1}$ & $K_{\mathrm{L}}, \mathrm{L} \mathrm{mM}^{-1}$ & $R^{2}$ \\
\hline Chloride & $33.4 \pm 9.7$ & $52.4 \pm 20.2$ & 0.95 \\
Acetate & $14.2 \pm 2.1$ & $76.1 \pm 23.9$ & 0.98 \\
Nitrate & $16.8 \pm 1.1$ & $40.9 \pm 4.8$ & 0.97 \\
\hline
\end{tabular}

Table 2. Balance of displaced exchangeable cations at the adsorption of $\mathrm{Pb}$ by an ordinary chernozem from metal nitrite, acetate, sulfate and chloride solutions, $\mathrm{mM} \mathrm{kg}^{-1}$

\begin{tabular}{|c|c|c|c|c|c|c|}
\hline Cads. & $\mathrm{Ca}^{2+}$ & $\mathrm{Mg}^{2+}$ & $\mathrm{Na}^{+}$ & $\mathrm{K}^{+}$ & $\begin{array}{l}\Sigma \text { displaced } \\
\text { exchangeable cations }\end{array}$ & $\begin{array}{l}\Sigma \text { displaced } \\
\text { exchangeable cations/Cads. }\end{array}$ \\
\hline \multicolumn{7}{|c|}{$\mathrm{Pb}\left(\mathrm{NO}_{3}\right)_{2}$} \\
\hline 0.98 & 2.00 & 0.36 & 0.18 & 0.06 & 2.60 & 2.65 \\
\hline 1.58 & 2.40 & 0.50 & 0.17 & 0.08 & 3.15 & 1.99 \\
\hline 1.96 & 2.40 & 0.40 & 0.25 & 0.15 & 3.20 & 1.63 \\
\hline 5.90 & 6.20 & 1.80 & 0.60 & 0.30 & 8.90 & 1.51 \\
\hline 9.80 & 9.80 & 3.40 & 1.00 & 0.45 & 14.65 & 1.49 \\
\hline 15.60 & 14.00 & 5.00 & 1.80 & 0.96 & 21.76 & 1.39 \\
\hline 19.32 & 15.00 & 5.80 & 2.00 & 1.10 & 23.90 & 1.24 \\
\hline \multicolumn{7}{|c|}{$\mathrm{Pb}\left(\mathrm{CH}_{3} \mathrm{COO}\right)_{2}$} \\
\hline 0.98 & 1.80 & 0.16 & 0.06 & 0.04 & 2.06 & 2.10 \\
\hline 1.58 & 2.20 & 0.20 & 0.10 & 0.06 & 2.56 & 1.62 \\
\hline 1.98 & 2.20 & 0.30 & 0.20 & 0.10 & 2.80 & 1.41 \\
\hline 5.96 & 6.20 & 1.60 & 0.40 & 0.25 & 8.45 & 1.42 \\
\hline 9.90 & 8.40 & 3.20 & 0.86 & 0.36 & 12.82 & 1.29 \\
\hline 15.76 & 13.00 & 4.60 & 1.50 & 0.84 & 19.94 & 1.27 \\
\hline 19.64 & 14.00 & 5.60 & 1.80 & 0.98 & 22.38 & 1.14 \\
\hline \multicolumn{7}{|l|}{$\mathrm{PbCl}_{2}$} \\
\hline 0.98 & 12.80 & 5.20 & 2.10 & 1.80 & 21.90 & 22.35 \\
\hline 1.94 & 12.20 & 5.20 & 2.30 & 1.90 & 21.60 & 11.13 \\
\hline 1.98 & 15.20 & 5.60 & 2.40 & 2.00 & 25.20 & 12.73 \\
\hline 5.96 & 14.60 & 5.80 & 2.40 & 2.01 & 24.81 & 4.16 \\
\hline 9.94 & 16.40 & 6.40 & 2.50 & 2.04 & 27.34 & 2.75 \\
\hline 15.88 & 20.60 & 7.00 & 2.50 & 2.20 & 32.30 & 2.03 \\
\hline 19.84 & 22.00 & 7.20 & 2.60 & 2.35 & 34.15 & 1.72 \\
\hline
\end{tabular}

Table 3. Data on the $\mathrm{pH}$ of the salt solutions used (above the line) and the equilibrium suspensions of an ordinary chernozem during the adsorption of $\mathrm{Pb}$ (under the line)

\begin{tabular}{llll}
\hline Cini, $\mathrm{mmol} \mathrm{L}^{-1}$ & $\mathrm{PbCl}_{2}$ & $\mathrm{~Pb}\left(\mathrm{CH}_{3} \mathrm{COO}\right)_{2}$ & $\mathrm{~Pb}\left(\mathrm{NO}_{3}\right)_{2}$ \\
\hline 0.05 & $5.6 / 6.8$ & $6.4 / 7.0$ & $6.3 / 7.0$ \\
0.08 & $5.5 / 6.8$ & $6.4 / 7.0$ & $6.1 / 6.7$ \\
0.1 & $5.5 / 6.7$ & $6.3 / 6.7$ & $5.9 / 6.7$ \\
0.3 & $5.4 / 6.6$ & $6.2 / 6.5$ & $5.8 / 6.5$ \\
0.5 & $5.3 / 6.6$ & $6.1 / 6.4$ & $5.6 / 6.4$ \\
0.8 & $5.3 / 6.5$ & $6.0 / 6.3$ & $5.4 / 6.3$ \\
1.0 & $5.3 / 6.4$ & $6.0 / 5.9$ & $5.2 / 6.2$ \\
\hline
\end{tabular}

The values of $K_{L}$ vary in the following series: $\mathrm{Ac}^{-}>$ $\mathrm{Cl}^{-}>\mathrm{NO}_{3}^{-}$.

The adsorption of metal by the ordinary chernozem was accompanied by the displacement of $\mathrm{Ca}^{2+}, \mathrm{Mg}^{2+}, \mathrm{K}^{+}$, $\mathrm{Na}^{+}$and $\mathrm{H}^{+}$into the solution (Table 2).

The value of the suspension $\mathrm{pH}$ varies during the adsorption of $\mathrm{Pb}$ (Table 3). According to the effect on the $\mathrm{pH}$ value, the acid anions form the following series: $\mathrm{NO}_{3}^{-}>\mathrm{Ac}^{-} \geq \mathrm{Cl}^{-}$.

Chemical properties of the anions associated not only affect the adsorption characteristics metal quantitative, but also on the mechanisms of their interaction with the surface of soil particles and metals in the form of finding the solid phase (Minkina et al., 2008). To answer this question studied desorption exchange forms of $\mathrm{Pb}$ cations adsorbed from soil solutions of chlorides, acetates and nitrates, ammonium acetate buffer ( $\mathrm{pH} 4.8$ ).

For the effect of the anions on the extraction of the adsorbed cations from the soil, it could be noted that the extraction of $\mathrm{Pb}$ progressively decreases in the series:

$$
\mathrm{Cl}^{-}>\mathrm{Ac}^{-}>\mathrm{NO}_{3}^{-}
$$




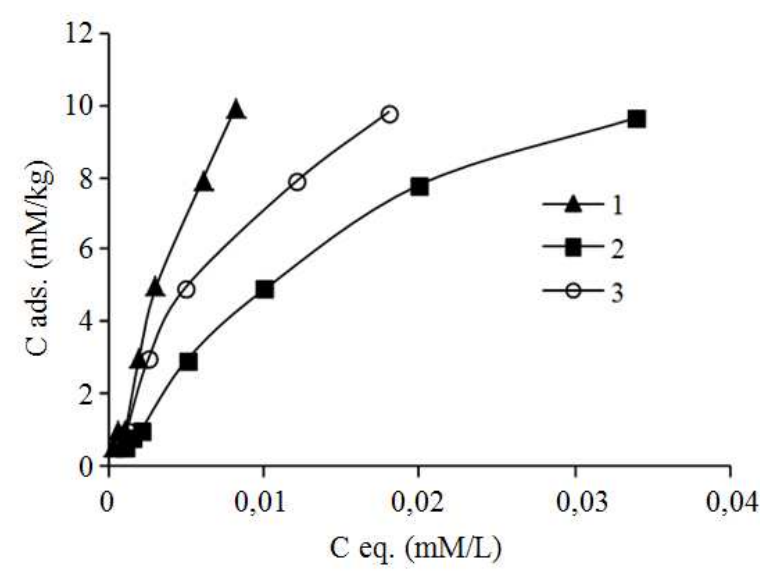

Fig. 1. Isotherms of the adsorption of $\mathrm{Pb}$ by an ordinary chernozem at their addition in the form of (1) chlorides, (2) nitrates (3) and acetates

\section{Discussion}

\section{Lead Adsorption}

The positions of the anions in the affinity series for the values of $C \max$ and $K \mathrm{~L}$ do not coincide. The soluble complexes of the studied HM cations with nitrate ions are the least stable and, hence, least affect the behavior of the $\mathrm{Pb}$ in adsorption processes, while the acetate anions form relatively stable complexes with the studied cation. In this case, the adsorption of the associated $\mathrm{Pb}$ forms with changes in the interaction mechanism is possible. The studied system, which includes only three anions, is incomplete. Actually, the behavior of the studied HMs is also affected by other anions always present in natural solutions- $\mathrm{CO}_{3}{ }^{2-}$, $\mathrm{HCO}_{3}{ }^{-}$and $\mathrm{OH}^{-}$as well as anions of dissolved organic acids (Kurochkina and Pinskii, 2004).

Thus, the effect of the attendant anions on the adsorption of HM cations by soils generally is retained and corresponds to the stability constants of the complexes formed by the studied metals with the attendant anions present in the liquid phase of the studied systems (Lur'e, 1971; Pagenkopf, 1978): $\mathrm{CO}_{3}{ }^{2-}>\mathrm{OH}^{-}>\mathrm{HCO}_{3}{ }^{-}>\mathrm{SO}_{4}{ }^{2-}>\mathrm{Ac}^{-}>\mathrm{Cl}^{-}>\mathrm{NO}_{3}{ }^{-}$. The $\mathrm{Pb}$ complexes with $\mathrm{Cl}^{-}$and $\mathrm{NO}_{3}{ }^{-}$anions are the least stable.

\section{Displacing of Exchangeable Cations at the Adsorption of $\mathrm{Pb}$}

The contents of the displaced exchangeable cations form the following series: $\mathrm{Ca}^{2+}>\mathrm{Mg}^{2+}>\mathrm{Na}^{+}>\mathrm{K}^{+}>>$ $\mathrm{H}^{+}$, which corresponds to their proportions in the SEC. The content of hydrogen atoms involved in the exchange processes is significantly lower than the concentrations of the other cations under study and has almost no effect on their sum; therefore, it is not considered in the balance calculations (Table 2).

Changes in the Soil Suspension $p H$ at the Interaction with $\mathrm{Pb}$ Salts

The changes in the suspension $\mathrm{pH}$ at the addition of $\mathrm{Pb}$ salts to the soil are due to the following main processes: The hydrolysis of HM salts, the adsorption of HM ions and protons by the SEC and the association of $\mathrm{HM}$ cations with the anions present in the solution: $\mathrm{OH}^{-}, \mathrm{SO}_{4}{ }^{2-}, \mathrm{Cl}^{-}, \mathrm{NO}_{3}{ }^{-}$and $\mathrm{Ac}^{-}$. The comparison of the data on the changes in the $\mathrm{pH}$ of the soil suspensions due to the hydrolysis of the original salts and the adsorption of metal by the soil (Table 3) shows that these processes can activate or inhibit each other. Thus, the hydrolysis of the studied salts decreases the solution $\mathrm{pH}$ with the increasing concentration of salts. This difference is primary due to the different Bronsted-Lowry acidities of the attendant anions: Sulfuric, hydrochloric and nitric are strong acids and acetic is a weak acid.

The calculation of the state of the $\mathrm{Pb}$ cations in the equilibrium solutions of the soils studied in the $\mathrm{pH}$ range of 5.8-7.2 showed that the acetate ions present in the solution fix up to $20 \%$ into relatively stable charged $\mathrm{MeAc}^{+}$complexes (Minkina et al., 2011). The concentration of the neutral carbonate complexes $\mathrm{PbCO}_{3}{ }^{0}$ also increases with the increasing $\mathrm{pH}$.

The addition of soil to the solution significantly changes the situation. The HM cations are capable of displacing the exchangeable hydrogen from the SEC and, hence, acidifying the equilibrium solutions. An inverse process occurs simultaneously: Protons, which have an extremely high affinity for the weak acidic components of the SEC, are absorbed by them (Pinskii, 1997). In addition, acetate anions are actively adsorbed by soils and the acidification enhances this process due to the protonation of the surface of highly dispersed phases. The superposition of these processes forms a relatively complex pattern of $\mathrm{pH}$ changes at the adsorption of HMs from different salt solutions by soils. The situation is even more complicated because of the participation of the alkali earth cations $\left(\mathrm{Ca}^{2+}\right.$ and $\mathrm{Mg}^{2+}$ displaced into the solution) in these processes. Analogous processes also occur at the adsorption of the $\mathrm{Pb}^{2+}$ cations. In particular, the precipitation of insoluble carbonates, oxycarbonates and hydroxides is typical for $\mathrm{Pb}$ (Forano et al., 2006). The use of the synchronous Xray technique allowed experimentally proving the existence of some stable $\mathrm{Pb}$ compounds in soils. These are primarily organic metal chelate complexes, forms sorbed by iron and manganese hydroxides and insoluble phosphates (Kretzschmar et al., 1999; 
Lamoureux et al., 2001; Manceau et al., 2002; 1996; Vodyanitskii, 2006). The possibility of the formation of insoluble $\mathrm{Pb}$ hydroxypyromorphite was shown earlier (Pinskii and Fiala, 1991).

\section{Assessing the Equivalence of the Exchange between the $\mathrm{Pb}$ and the SEC Cations}

The sum of the exchangeable cations displaced into the solution is generally significantly larger than the amount of the adsorbed metal and the ratio between the sum of the exchangeable cations displaced into the solution and the amount of the adsorbed HMs is almost always higher than 1 and decreases with the increasing amount of the adsorbed HM. Ion exchange processes in soils by definition occur in equivalent proportions; therefore, the question arises concerning the reasons for the observed disagreement between the contents of the metal adsorbed by the soil and the exchangeable cations displaced into the solution.

The content of the exchangeable cations released into the solution depends on the properties of the adsorbed $\mathrm{Pb}$ cations and the attendant anions (Table 2 ), as well as on the composition and properties of the SEC (Minkina et al., 2009). From the mean total concentrations of the exchangeable cations in the equilibrium solutions, the displacing capacities of the studied metal can be assessed.

By the effect of the anions on the displacing capacity of the $\mathrm{Pb}$ cations, the following series are formed: $\mathrm{Cl}^{-}>>$ $\mathrm{NO}_{3}^{-}>\mathrm{Ac}^{-}$.

The association of HM cations with the solution components plays an important though uncertain role not only in the adsorption of HM cations but also in the interaction with the exchangeable cations released into the solution (Minkina et al., 2014; Pinskii and Zolotareva, 2004; Pinskii et al., 2014). The effect of the attendant cations on the displacing capacity of the $\mathrm{Pb}$ does not correlate with the stability constants of the complexes of the metal with the corresponding anions (Lur'e, 1971; Pagenkopf, 1978). $\mathrm{MeAc}^{+}$and $\mathrm{MeSO}_{4}{ }^{0}$ are the most stable complexes of the studied metal, while the $\mathrm{MeNO}_{3}{ }^{+}$and $\mathrm{MeCl}^{+}$complexes are less stable and are formed in smaller amounts. On the other hand, the $\mathrm{HCO}_{3}{ }^{-}$and $\mathrm{OH}^{-}$anions, which are always present in the solutions, also form relatively stable charged complexes with $\mathrm{Pb}^{2+}$ and thus affect the behavior of $\mathrm{HMs}$ in the systems studied. The formation of charged metal complexes with inorganic and organic anions in the solution changes the mechanisms of interaction with the solid phase surface, which increases the amount of the adsorbed $\mathrm{Pb}$. More complex interactions of the associated HM cations with the solid phase surface are also possible (Davis and Leckie, 1978; Minkina et al., 2009; Benjamin and Leckie, 1982; Pinskii, 1988).
The super equivalent displacement of exchangeable cations at the adsorption of metal by the soil is explained by the presence of some amounts of $\mathrm{Ca}$ and $\mathrm{Mg}$ carbonates, as well as precipitates of the soluble salts of the main exchangeable cations in the original soil. The excess of the salts displaced into the solution regularly decreases with the increasing amount of the adsorbed $\mathrm{Pb}$, because the exchange of cations occurs in equivalent proportions and the content of soluble salts remains constant. As a result, the $\Sigma$ displaced exchangeable cations $/ \mathrm{C}_{\mathrm{ads}}$ ratio decreases, but it usually remains higher than 1 . The adsorption of associated metal forms $\mathrm{MeL}^{+}$(where L is a singly charged ligand) also can cause a decrease of this ratio, because it is formally accompanied by an increase in the content of the adsorbed HM cations and, hence, the denominator of the ratio. The formation of associates can significantly change the mechanism of metal adsorption.

Another mechanism of the unexchangeable adsorption of HMs by the soil is the formation of insoluble compounds localized on the surface. The probability of such processes was experimentally proved using EXAFS spectroscopy (Vodyanitskii, 2006). Calculations showed (Minkina et al., 2009) that the precipitation of $\mathrm{Pb}$ hydroxide is possible under these experimental conditions. A significant contribution is made by the hydrolysis of compounds on the surface of soil particles, which proceeds relatively rapidly. This is also a source of additional ions in the equilibrium solution (Minkin et al., 1982).

\section{Pb Sorbtion-Desorbtion}

The data of Table 4 shows that in all cases the amount of desorbed cations substantially less than the amount absorbed. Hence, the single extraction of the exchangeable $\mathrm{Pb}$ cations by this extracting agent does not ensure their total transfer into the solution. Sadovnikova (1997) noted that a single treatment with $1 \mathrm{~N} \mathrm{NH}_{4} \mathrm{Ac}$ does not completely displace the exchangeable forms of $\mathrm{Pb}$, because it extracts no more than $50 \%$ of the exchangeable alkaline-earth cations, which are significantly weaker retained by the soil than the HMs.

When the content of the adsorbed $\mathrm{Pb}$ cations increases, both the absolute amount of the desorbed $\mathrm{Pb}$ cations and the percentage of their desorption increase. This fact confirms the common idea that the binding of the adsorbed cations to the soil particles becomes weaker because of the energetic heterogeneity of the surface and the mutual effect of the adsorbed cations. As far as the surface is filled with adsorbed cations, they occupy positions with progressively lower affinities for these cations, which increases their mobility and availability to plants and microorganisms. 
Table 4. Contents of the adsorbed and extracted $\mathrm{Pb}$ cations from an ordinary chernozem contaminated with different metal salts, $\mathrm{mM} \mathrm{kg}^{-1}$

\begin{tabular}{|c|c|c|c|c|c|}
\hline \multicolumn{2}{|l|}{ Chlorides } & \multicolumn{2}{|l|}{ Acetates } & \multicolumn{2}{|l|}{ Nitrates } \\
\hline The adsorbed & The extracted & The adsorbed & The extracted & The adsorbed & The extracted \\
\hline 0,50 & 0,18 & 0,50 & 0,05 & 0,49 & 0,03 \\
\hline 0,99 & 0,21 & 0,99 & 0,15 & 0,98 & 0,11 \\
\hline 2,98 & 0,85 & 2,98 & 0,93 & 2,95 & 0,35 \\
\hline 4,97 & 1,98 & 4,958 & 1,73 & 4,90 & 0,86 \\
\hline 9,92 & 3,80 & 9,82 & 3,74 & 9,66 & 1,90 \\
\hline
\end{tabular}

\section{Conclusion}

In general, the behavior of the metal in the soil, the solution greatly depends on the individual circumstances. The $\mathrm{Cl}^{-}, \mathrm{Ac}^{-}$and $\mathrm{NO}_{3}^{-}$anions significantly affect the adsorption of $\mathrm{Pb}$ cations by ordinary chernozem. Almost all isotherms are adequately described by the Langmuir equation. Soluble complexes investigated $\mathrm{Pb}$ cations from nitrate ions, the least stable and hence less likely affect the behavior of the metal in the adsorption process, while the anions of acetic acid to form sufficiently stable complexes with $\mathrm{Pb}$. The chloride anion occupies an intermediate position.

The involvement of all the cations and different anions present in the system and capable of exchange in the sorption is an important aspect of adsorption processes in natural soils. The anionic composition of the salt containing a HM can have a qualitative and quantitative effect on the exchange of cations in the soil-solution system.

It was shown that the adsorption of $\mathrm{Pb}$ by the soil from different salt solutions is accompanied by the displacement of exchangeable cations and protons into the solution in proportions typical for the studied soil: $\mathrm{Ca}^{2+}>\mathrm{Mg}^{2+}>\mathrm{Na}^{+}>\mathrm{K}^{+}>>\mathrm{H}^{+}$. The sum of the displaced exchangeable cations always exceeds the amount of the adsorbed HM cations. This is related to the presence of soluble salt precipitates in the soil.

The effect of the attendant anions on the $\mathrm{pH}$ of the equilibrium solutions is uncertain because of the simultaneous action of three main processes: The hydrolysis of HM salts, the adsorption (displacement) of protons from the SEC at the adsorption of HMs and the association of $\mathrm{HM}$ cations with the anions present in the solution: $\mathrm{OH}^{-}, \mathrm{SO}_{4}^{2-}, \mathrm{Cl}^{-}, \mathrm{NO}_{3}^{-}$and $\mathrm{Ac}^{-}$. According to the effect on the $\mathrm{pH}$ value, the acid anions form the following series: $\mathrm{NO}_{3}^{-}>\mathrm{Ac}^{-} \geq \mathrm{Cl}^{-}$.

The sum of the exchangeable cations displaced into the solution always exceeds the amount of the adsorbed metal and the ratio between the sum of the exchangeable cations displaced into the solution and the amount of the adsorbed $\mathrm{Pb}$ is always higher than 1 and decreases with the increasing content of the adsorbed metal.

The content of $\mathrm{Pb}$ cations desorbed by the ammonium acetate buffer solution ( $\mathrm{pH} 4.8$ ) makes up $6-39 \%$ of the total $\mathrm{Pb}$ adsorbed cations. According to the effect of anions on the displacing capacity of $\mathrm{Pb}$ cations, the following series are found: $\mathrm{Cl}^{-}>\mathrm{Ac}^{-}>\mathrm{NO}_{3}{ }^{-}$.

\section{Acknowledgement}

This work was supported by the Ministry of Education and Science of the Russian Federation, project no. 5.885.2014/K. Analytical work was carried out on the equipment of Centers for collective use of Southern Federal University "High Technology", grant RFMEFI59414X0002.

\section{Funding Information}

The funders of this manuscript were the Ministry of Science of the Russian Federation.

\section{Author's Contributions}

Tatiana M. Minkina: The head of the investigation, designed the research plan and organized the study, coordinated the data-analysis and contributed to the writing of the manuscript.

David L. Pinskii: Designed the research plan, organized the study and contributed to the writing of the manuscript.

Saglara S. Mandzhieva: Coordinated the dataanalysis and contributed to the writing of the manuscript.

Tatiana V. Bauer: Participated in all experiments and coordinated the data-analysis.

Abdulmalik A. Batukaev: Contributed in drafting the manuscript and reviewing it critically for significant intellectual content

Svetlana N. Sushkova: Collected the field data, performed the statistical analysis.

Aleksey K. Sherstnev: Collected the field data, determined the $\mathrm{Pb}$.

Serozhdin U. Bakoev: Performed the statistical analysis.

\section{Ethics}

This article is original and contains unpublished material. The corresponding author confirms that all of other authors have read and approved the manuscript and no ethical issues involved. 


\section{References}

AMSS, 1990. Agrochemical methods of soil studies. Moscow, Russia.

Benjamin, M.M. and J.O. Leckie, 1982. Effects of complexation by chloride, sulfate and thiosulfate on adsorption behavior of cadmium on oxide surfaces. Environ. Sci. Technol., 16: 162-170. DOI: $10.1021 / \mathrm{es} 00097 \mathrm{a} 008$

Davis, J.A. and J.O. Leckie, 1978. Effect of adsorbed complexing ligands on trace metal uptake by hydrous oxides. Environ. Sci. Technol., 12: 1309-1315. DOI: $10.1021 / \mathrm{es} 60147 \mathrm{a} 006$

FAO, 1988. Yearbook of forest products. Food and Agriculture Organization of the United Nations, Rome.

Forano, C., T. Hibino, F. Leroux and C. Taviot-Gueno, 2006. Layered Double Hydroxides. In: Handbook of Clay Science, Bergaya, F., B.K.G. Theng and G. Lagaly (Eds.), Elsevier, Amsterdam, ISBN-10: 0080441831, pp: 1021-1095.

Gorbatov, V.S., 1988. Stability and transformation of the oxides of heavy-metals ( $\mathrm{Zn}, \mathrm{Pb}, \mathrm{Cd})$ in soils. Soviet Soil Sci., 20: 82-90.

Guilherme, L.R.G., M.A.P. Pierangeli, N. Curi, S.J. Anderson and J.M. Lima, 2003. Adsorption/desorption of lead, copper and cadmium on oxidic soils as affected by phosphate pretreatment. Proceedings 7th International Conference on the Biogeochemistry of Trace Elements, Jun. 15-19, Uppsala, Sweden, pp: 140-141.

Kretzschmar, R., I. Christl and W. Zhou, 1999. Competitive sorption of $\mathrm{Cu}$ and $\mathrm{Pb}$ to Hematite: macroscopic, modeling and EXAFS results. Proceedings of the 5th International Conference ICOBTE on the Biogeochemistry of Trace Elements, Jul. 11-15, Vienna, Austria, pp: 342-343.

Kurochkina, G.N. and D.L. Pinskii, 2004. The formation of mineral-organic compounds and their effect on the surface properties of soil aluminosilicates. Euras. Soil Sci., 37: 378-387.

Ladonin, D.V. and M.M. Karpukhin, 2011. Fractional composition of nickel, copper, zinc and lead compounds in soils polluted by oxides and soluble metal salts. Euras. Soil Sci., 44: 874-885. DOI: $10.1134 / \mathrm{S} 1064229311040053$

Lamoureux, M.M., N. Warner and N. Nizam, 2001. X-Ray absorption fine structure spectroscopy: shining new lights on metal speciation of environmental solids. Proceedings of the 6th International Conference ICOBTE on the Biogeochemistry of Trace Elements, Jul. 11-15, Vienna, Austria, pp: 120-120.
Lur'e, Y.Y., 1971. Handbook on Analytical Chemistry. 1st Edn., Khimiya, Moscow, Russia, pp: 456.

Manceau, A., M.A. Marcus and N. Tamura, 2002. Quantitative speciation of heavy metals in soils and sediments by synchrotron X-ray technique. Rev. Mineral. Geochem., 49: 341-428.

DOI: 10.2138 /gsrmg.49.1.341

Manceau, A., M.C. Boisset and G. Sarret, 1996. Direct determination of lead speciation in contaminated soils by EXAFS spectroscopy. Environ. Sci. Technol., 30: 1540-1552. DOI: 10.1021/es9505154

Minkin, M.B., N.I. Gorbunov and P.A. Sadimenko, 1982. Topical Issues in the Physical and Colloidal Chemistry of Soils. 1st Edn., Rostov-on-Don, Russia, pp: 280.

Minkina, T.M., D.L. Pinskii, A.P. Samokhin, V.S. Kryshchenko and Y.I. Gaponova et al., 2009. Effect of attendant anions on the adsorption of Zinc, Copper and lead by chernozem. Euras. Soil Sci., 42: 516-522. DOI: 10.1134/S1064229309050068

Minkina, T.M., D.L. Pinskii, S.S. Mandzhieva, E.M. Antonenko and S.N. Sushkova, 2011. Effect of the particle-size distribution on the adsorption of copper, lead and zinc by Chernozemic soils of Rostov oblast. Euras. Soil Sci., 44: 1193-1200. DOI: $10.1134 / \mathrm{S} 1064229311110044$

Minkina, T.M., D.L. Pinskiy, T.V. Bauer, S.S. Mandzhieva and O.N. Belyaeva et al., 2014. Effect of attendant anions on zinc adsorption and transformation in chernozem. J. Geochem. Exp., 144: 226-229. DOI: 10.1016/j.gexplo.2013.12.016

Minkina, T.M., G.V. Motuzova, O.G. Nazarenko, V.S. Kryshchenko and S.S. Mandzhieva, 2008. Forms of heavy metal compounds in soils of the steppe zone. Euras. Soil Sci., 41: 708-716. DOI: $10.1134 / \mathrm{S} 1064229308070053$

Pagenkopf, G.K., 1978. Introduction to Natural Water Chemistry. 1st Edn., Marcel Dekker, New York, ISBN-10: 0824767063, pp: 272.

Panin, M.S. and T.I. Siromlya, 2005. Adsorption of copper by soils of the Irtysh River region, Semipalatinsk oblast. Euras. Soil Sci., 38: 364-373.

Parnunina, R.I., 1983. Cadmium status in soddypodzolic soils and cadmium uptake by plants. Extended Abstract of Candidate Science Dissertation, Moscow, Russia.

Pinskii, D.L. and B.N. Zolotareva, 2004. The behavior of $\mathrm{Cu}(\mathrm{II}), \mathrm{Zn}(\mathrm{II}), \mathrm{Pb}(\mathrm{II})$ and $\mathrm{Cd}(\mathrm{II})$ in a solution-natural sorbent system in the presence of fulvic acid. Euras. Soil Sci., 37: 249-257.

Pinskii, D.L. and K. Fiala, 1991. Chemistry of heavy metals in the environment. Pollutants in the Environment, Priroda, Pushchino, Russia. 
Pinskii, D.L., 1988. The problem of the mechanisms of ion-exchange adsorption of heavy metals in soils. Euras. Soil Sci., 31: 1223-1230.

Pinskii, D.L., 1997. Ion-Exchange Processes in Soils. 1st Edn., RAN, Pushchino, Russia, ISBN-10: 5201143369, pp: 166.

Pinskii, D.L., T.M. Minkina, S.S. Mandzhieva, U.A. Fedorov and T.V. Bauer et al., 2014. Adsorption features of $\mathrm{Cu}(\mathrm{II}), \mathrm{Pb}(\mathrm{II})$ and $\mathrm{Zn}(\mathrm{II})$ by an Ordinary Chernozem from Nitrate, Chloride, Acetate and Sulfate Solutions. Euras. Soil Sci., 47: 10-17. DOI: $10.1134 / \mathrm{S} 1064229313110069$

Puls, R.W. and R.W. Bohn, 1988. Sorption of cadmium, nickel and zinc by kaolinite and montmorillonite suspensions. Soil Sci. Society Am. J., 52: 1289-1292.

DOI: $10.2136 /$ sssaj1988.03615995005200050013x
Sadovnikova, L.K., 1997. The use of soil extracts for studying heavy metal compounds. J. Khim. Sel'sk. Khoz., 2: 37-40.

Vodyanitskii, Y.N., 2006. Arsenic, lead and zinc compounds in contaminated soils according to EXAFS spectroscopic data: A review. Euras. Soil Sci., 39: 611-621.

DOI: $10.1134 / \mathrm{S} 1064229306060056$

Wang, J.J. and D.L. Harrell, 2005. Effect of ammonium, potassium and sodium cations and phosphate, nitrate and chloride anions on zinc sorption and lability in selected acid and calcareous soils. Soil Sci. Society Am. J., 69: 1036-1046. DOI: 10.2136/sssaj2004.0148

Zaplina, M.A., 1994. Transformation and transport of lead, cadmium and zinc-oxides in a sod-podzolic soil. Euras. Soil Sci., 28: 32-40. 